\title{
GREAT BLUE HERON SWIMMING
}

\section{by R. Wayne Campbell, 5536 Hardwick St., Burnaby, B.C.}

Most ornithologists regard Great Blue Herons (Ardea herodias) not as swimmers, but as graceful, longlegged birds that spend much of their time wading in shallow marshes and quiet lagoons in search of food. Along the British Columbia coast, tidal marshes are favorite foraging areas for these birds. While photographing herons feeding on speckled sanddabs (Citharichthyes stigmaeus) in this habitat near the Vancouver International Airport, B.C. on February 14, 1968 I observed an unusual incident of a Great Blue Heron swimming.

About 300 feet to sea from my hide two Great Blue Herons were resting on a driftlog, about four feet in length. One bird left the $\log$ and alighted on the water nearby and started splashing. Through $8 \times 40$ binoculars I watched the bird bathe itself for approximately four minutes. The heron would commence each bathing series by dipping its entire head under water. This would be followed by a distention of the neck, then both head and neck were raised from the water and the wings flapped vigorously for five to 10 seconds.

The second heron, in the meantime, left the $\log$ and alighted only momentarily near the bathing bird. With ease the bird lifted itself from the water and flew back to the driftlog.

After bathing for about five minutes the heron on the water began swimming ashore. The bird sat quite low in the water and in silhouette resembled a large Western Grebe. It swam with neck bent and wings folded high on its back. The swimming motion was jerky, similar to that of an American Coot. I could not see the movement of legs and feet and therefore cannot comment on the actual swimming process.

The bird swam about 200 feet and waded the remaining distance to shore. Once ashore, among other herons, the bird preened itself. About
10 minutes later I flushed the herons from the beach and checked for possible injury in the swimming heron. The bird's flight, however, was strong and direct.

The following day I visited the same area on a low tide and checked for possible shoals but found the probable depth of water sufficient to swim in.

The swimming habit of the Great Blue Heron has been reported by several writers. Their observations, however, differ somewhat from the one described above. Bent (U.S. Nat. Museum Bull. 135:110, 1926), Jenson (Auk, 47:245-6, 1930) and Roberts (Birds of Minnesota, vol. 1, p. 178, 1932) report Great Blue Herons alighting on water and swimming for the purpose of catching fish. Slipp and Flahaut (Murrelet, 22:55-6, 1941) attribute their two observations of swimming Great Blue Herons to "impaired powers of flight."

\section{VISIT THE MAURICE G. STREET WILDLIFE SANCTUARY}

Blue Jay readers are reminded that the SNHS Summer Meeting will be held this year in the Maurice G. Street Wildlife Sanctuary at Nipawin. This will be an opportunity to visit the new sanctuary.

The dates are June 14-16 and the headquarters for registration and field trip departure will be the Legion Hall, Nipawin. Details appeared in the last Newsletter. For last-minute reservations, telephone Mrs. George Grieve, Nipawin.

\section{PRAIRIE NEST RECORDS SCHEME}

Contributors to the Prairie Nest Records Scheme are reminded that good records of even the commonest species are needed. Write to Dr. Robert W. Nero, Manitoba Museum of Man and Nature, 147 James Avenue, Winnipeg 2, Manitoba for nest record cards and send your completed cards back to him at the end of the season. 